\title{
UVODNIK
}

\section{OBOROŽENE SILE DANES}

Leto 2016 je za Republiko Slovenijo zelo pomembno. Spominjamo se namreč, kako smo se državljanke in državljani pred 25 leti odločili za samostojno in demokratično pot, za pot pomembnih odločitev in sprememb. Veliko se je zgodilo od takrat. Nabrali smo si veliko izkušenj, več znamo in vemo. Ob pomembnih obletnicah navadno namenjamo veliko pozornosti mejnikom, ki so prehojeno pot zaznamovali. Pri obletnicah in zgodovinskem spominu pa nas navdušuje tudi, da iz njih lahko črpamo zamisli za prihodnost.

V uredniškem odboru Sodobnih vojaških izzivov smo si za letos postavili cilj, da z zadnjo številko letnika, ki bo imela naslov Republika Slovenija - prvih samostojnih petindvajset let $v$ mednarodnem varnostnem okolju in bo izšla decembra, počastimo petindvajset let samostojne Slovenije. Za to številko si želimo prispevke, ki kažejo na poznavanje slovenske zgodovine in izkušenj na področju varnosti, obrambe in vojaštva, a so obogateni s poudarkom na aktualnih vsebinah in predlogih za njeno prihodnost znotraj mednarodnega varnostnega okolja.

Tretja številka, ki bo izšla oktobra, bo imela naslov Mednarodna varnostna skupnost na razpotju. Pričakujemo prispevke o novostih, ki jih prinašata vrh Nata v Varšavi in nova evropska obrambna strategija, o različnih aktualnih varnostnih tveganjih, predvsem pa mogočih odzivih nanje. Pri odzivih na varnostna tveganja je ključna preventiva, kot so predvidevanja, načrtovanje, oblikovanje in usklajevanje strategij ter na koncu njihovo kakovostno uresničevanje.

Druga številka v osemnajstem letu izhajanja bo naslovljena Ženske, mir in varnost ob 15. obletnici Resolucije VS OZN 1325. V preteklosti sta v Sloveniji že izšla dva zbornika na temo žensk v oboroženih silah. Prvega je izdalo Ministrstvo za obrambo leta 1995, drugi pa je nastal leta 2002 v sodelovanju ministrstva s Fakulteto za družbene vede. To pa bo prva številka Sodobnih vojaških izzivov, ki bo namenjena tej temi. 
Prva številka letošnjega letnika ima naslov Oborožene sile danes.

Z izbranimi naslovi in temami se bomo tako leta 2016 posvetili preteklosti, sedanjosti in prihodnosti ter ženskam, miru in varnosti.

Prvi prispevek številke o oboroženih silah danes ima naslov Teoretični vidiki odnosa med strategijo in obrambnim planiranjem na varnostno-obrambnem in vojaškem področju. Pavel Vuk pravi, da »/.../ naložba države v razvijanje strateške misli ter planskega znanja in veščin ne bi smela biti predmet kalkulacije vloženih sredstev, ampak predmet dolgoročne investicije v razvijanje miselnih procesov, zamisli o prihodnjih vojaških ciljih, konceptih bojevanja in prihodnjih opcijah oboroženih sil,« in meni, da strategijo ter obrambno planiranje upravičeno uvrščamo med najpomembnejše in hkrati tudi najzahtevnejše aktivnosti vsake države.

Mehmedin Tahirović in Olivera Injac predstavljata Razvoj obrambnega sistema Črne gore. Kot pravita, ima vsaka država pri iskanju najboljšega modela za zaščito svoje varnosti tudi svoje strateške razloge in posebnosti, ter nadaljujeta, da so pri vključevanju $\mathrm{v}$ evroatlantske integracije reforme in graditev vseh elementov nacionalne varnosti Črne gore, še zlasti pa obrambnega sistema, veliko cenejši, raven njihove učinkovitosti pa je veliko višja.

Gostujoči obrambni atašeji: prednosti in pomanjkljivosti je naslov članka, v katerem nas Gregor Zupan seznanja z načini delovanja obrambnih atašejev, ki se zaradi zmanjševanja finančnih sredstev in vpliva sodobnih tehnologij v zadnjih letih pojavljajo predvsem kot rezidenčni ali gostujoči obrambni atašeji. V članku avtor razmišlja, kakšne so prednosti in slabosti enih in drugih, še posebno v funkciji razvoja diplomatske karierne poti.

Vinko Vegič piše o Pojavu in konceptualizaciji hibridnega vojskovanja. Izpostavlja vprašanja opredeljevanja koncepta hibridnega vojskovanja na splošno ter na primeru Ukrajine in tako imenovane Islamske države, pri čemer opredeli njegove temeljne značilnosti. V nadaljevanju razpravlja o možnostih in vprašanjih zoperstavljanja hibridnemu vojskovanju ter ugotavlja, da je tudi v Sloveniji nujen razmislek o tem, kaj nova strateška realnost, ki se trenutno kaže s pojavom hibridnega vojskovanja na vzhodnem in južnem obrobju Nata (Ukrajina, Sirija in Irak), prinaša v našo varnostno stvarnost.

Koncept ě̌aloniranja ognjev in sistemi ognjene podpore v Slovenski vojski je naslov teme, ki se ji je posvetil Viktor Potočnik. Kot pravi, je namen članka preprost: oblikovati pogled SV na vlogo in nalogo sistemov, ki zagotavljajo posredne ognje za ognjeno podporo na taktični ravni od ravni voda do brigade. V članku je to naredil z razlago koncepta ešaloniranja ognjev in njegovega pomena za uspeh ognja in manevra na bojišču. Ali mu je to uspelo oziroma kako, si lahko preberete v nadaljevanju. 
Na civilno-vojaško sodelovanje na splošno, še posebno pa v Natu in Evropski uniji, ter na posebnosti takega sodelovanja med oboroženimi silami in humanitarnimi organizacijami se je osredotočila Maja Garb v članku Razvoj pojma in koncepta civilno-vojaškega sodelovanja in usklajevanja v mirovnih operacijah. Ena izmed njenih sklepnih ugotovitev je, da pregled vsebine in uporabe termina civilnovojaško sodelovanje, najpogosteje znanega kot CIMIC, pokaže, da znotraj sodobnih mirovnih operacij tako v vsebini kot uporabi tega pojma ni enotnosti. Pa ne le to, srečamo celo nasprotovanje sodelovanju na terenu, kar vidimo zlasti v razmerju med humanitarnimi organizacijami in vojaškimi silami.

Andreas Hauptmann Kaiser je pripravil članek z naslovom Enote Nemške vojske za gorsko bojevanje, $\mathrm{v}$ katerem nam podrobno predstavlja namen, organiziranost in delovanje nemških enot za gorsko bojevanje, s poudarkom na 23. brigadi gorske pehote in vaji Edelweiss 2015.

Bralci Sodobnih vojaških izzivov ste kot vedno vabljeni $\mathrm{k}$ branju in pisanju prispevkov. 